\title{
Radical pedagogies and metamodelings of knowledge in the making
}

\author{
Erin Manning \\ Concordia University \\ Corresponding Author: erin.manning@concordia.ca
}

(Submitted: 13 February 2020; Accepted: 26 July 2020)

\begin{abstract}
Across three scenes, this proposition explores the place of knowledge in experience, asking how else we might think of radical pedagogy. Inspired by the work of Loris Malaguzzi and oriented by the wander lines of autistics who refuse to adapt to neurotypical modes of knowing, the hope is to follow transversal diagrams rather than premade maps of what education can be. Decolonial practices for rethinking education are central to this neurodiverse reorientation of the map.
\end{abstract}

Keywords: neurodiversity, neurotypicality, radical pedagogy, metamodeling, decolonization, Felix Guattari, Fernand Deligny, Loris Malaguzzi

\section{PART I: SCENES}

\section{Scene 1}

'But he has language also, in fact three languages,' argued the mother.

'He can't write,' reassured the doctors.

Tito Mukhopadhyay, The Mind Tree

\section{Scene 2}

The child has

a hundred languages

a hundred hands

a hundred thoughts

a hundred ways of thinking

of playing, of speaking.

a hundred always a hundred

ways of listening

And of the hundred 
they steal ninety-nine.

they tell the child: that work and play

reality and fantasy

science and imagination

sky and earth

reason and dream

are things

that do not belong together.

Loris Malaguzzi No Way. The Hundred is There

\section{Scene Three}

Maintaining the interstices, this should be the work of the maps that we trace.... The maps, we must return to them constantly, to what they should be and what they aren't, key as they are in the workings of the network. The maps of these recent times had a fault. They transcribed a recent event: we made them talk, they always turned around what had just happened, what was happening at that moment. But the real work of the maps ... is to retrace the wander line of a child and to notice that this wander line escapes us, that we do not catch at all that might be the child's project, to note that the wander lines are magnetized by something.

$[T]$ he maps of today are more attentive to wander lines. It is necessary to note that all does not happen simply between a close presence and a child. These are very particular moments, but the spider web of the network remains. And it is certain that our presence in a site while we are absent from it is language: the network is language since it is the consciousness that each of us has of the presence of the others. This is why we must not stubbornly trace only the pathways. ${ }^{1}$

Fernand Deligny, Au défaut du langage

\footnotetext{
${ }^{1}$ Fernand Deligny spent thirty years in Monoblet, France, facilitating encampments for autistics and rethinking practices established with Felix Guattari and Jean Oury at the La Borde clinic (where he worked in the early 1960s). Where Guattari's work is exemplary as regards psychopathy, Deligny's work is so for autistics. I wrote about Deligny's work in some detail in "The Shape of Enthusiasm" in Always More Than One (Duke UP, 2013). For an English translation of Deligny's writing see Arachnean and Other Texts. Translation by Drew Burk and Catherine Porter (Univocal, Minessota University Press, 2015).
} 


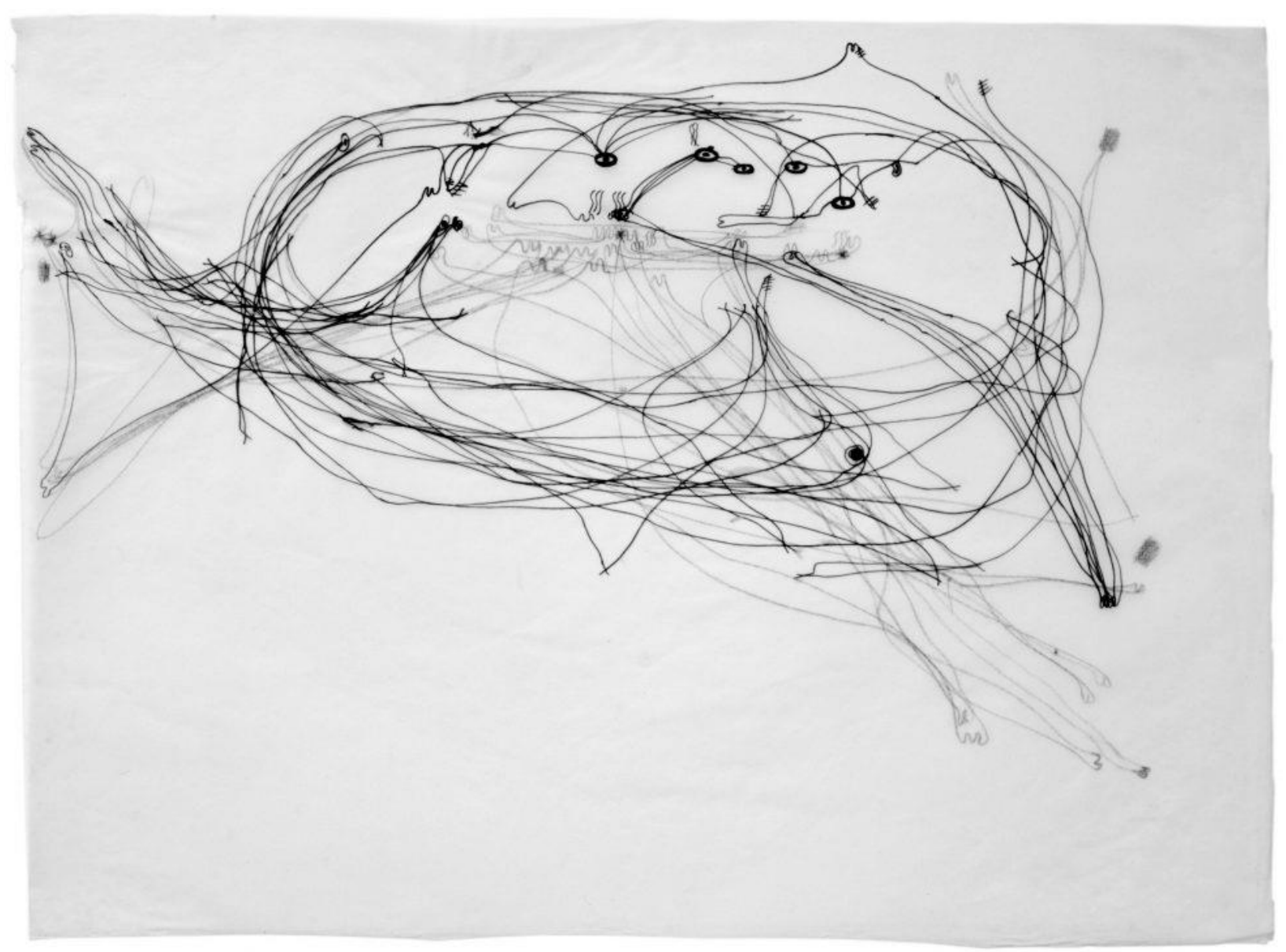

Figure 1: Wander lines

\section{Part 2: METAMODELING}

Félix Guattari's concept of metamodeling is concerned with an excess over models. In an ethos that challenges method, it asks what moves across experience that evades the frame. Transversality is its operative concept, reminding us that in excess of what moves between is the force that shifts the shape of the encounter: trans is not inter, it is across.

Metamodeling challenges normopathy at every turn, recognizing that the normative is located in the 'inter', in the assumption that all experience functions between existing categories. Metamodeling refuses models, proceeds from the transversal interstices, in the acrossness of what refuses to condemn itself to simple location, as Whitehead might say (1938: 188). Against simple location's misplaced concreteness, metamodeling draws schizoanalytic diagrams of lifeliving, diagrams that are always more than a passage from here to there, diagrams thick with the resonance of orientations fabulated, of turns not taken, languages unscripted. Metamodeling feels the pull of the line, following its magnetic impulse not toward an endpoint, but toward a retexturing of the relay that comes of the force of all that does not quite come into contact. 
During the 1960s, research groups were constituted in and around Paris to address the question of metamodelings for 'a living transdisciplinarity' (Guattari cited in Genosko, 2003: 135). ${ }^{2}$ Propositions for transdisciplinary research were eventually composed whose aim it was to embolden thinking across disciplinary boundaries, particularly those of psychology, philosophy, architecture, and urban planning, both in and outside academic and psychiatric institutions.

In the ethos of metamodeling, the question of the transversality of transdisciplinarity activated in the propositions below must therefore always be understood to exceed the site of the university and of any other factories of knowledge. The propositions are about living, about following a knowing that must always remain out of bounds. They must be understood not as a reclaiming of the site of knowledge as we live it but as an operation of transversality that challenges all the we have come to understand as knowledge, including our account of interdisciplinarity.

\section{Part 3: PROPOSITIONS}

1. call into question a given discipline's ability to understand the globality within which it finds itself;

2. adopt a humble attitude in the face of the immense field of knowledge of the real;

3. open one's own assemblages towards heterogeneous fields of dialogue and other forms of mutual exchange;

4. do not abandon specialization as an ideological principle but, rather, proceed irreversibly by fluctuation and bifurcation towards transdisciplinarity, each discipline according to its own speed and willingness to make sacrifices or suffer 'amputations';

5. certain theoretical approaches will need to be deconstructed, but hopefully not in an anarchic way so that existing disciplines may see the confluence of concepts and problems from a new theoretico-pragmatic and virtual perspective;

6. the creation of numerous cross-references is not heresy but has always existed to some extent;

7. from a critical interdisciplinary perspective, certain scientific positions of alleged selfsufficiency and omnipotence will be subject to definitive critique (no more queen of the sciences, no more pure [higher] and applied [lower], etc.);

8. intradisciplinary graspings of the virtualities of heterogeneous, evolving fields will have repercussions for the movement towards transdisciplinarity. (Guattari and Vilar cited in Genosko, 2003: 136-137)

\footnotetext{
${ }^{2}$ The first group was known as the Groupe de travail de psychologie et de sociologie institutionnelles (GTPSI), brought together around 1960. Fédération des groupes d'études et de recherches institutionnelles (FGERI) followed in 1965 and was composed of 'psychiatrists, analysts, anti-psychiatrists, architects,urbanists, activists ... Later, in 1968, FGERI would develop sub-groups such as CERFI (Centre d'études et de recherches sur le fonctionnement des institutions), which published the journal Recherches, the organ of institutional psychotherapy edited by Guattari' (Genosko, 2003: 130).
} 


\section{Part 4: TRANSVERSALITY}

1. A discipline carries the weight of an institutional matrix. It is a map, its contours drawn in advance. A language that speaks cogently of what is to be included and left out.

A discipline is not intransigent. Bent by the demands of the moment, it is capable of reorientation. Too much displacement and it loses its consistency, however. A certain dependence on the contour is required.

A discipline is a shorthand for what does not need to be said about how knowledge crafts itself in the formatting of what comes to be known as evaluation.

A discipline disciplines value.

In their reference to the globality of a discipline - 'call into question a given discipline's ability to understand the globality within which it finds itself' - Guattari and Vilar underscore the necessity of tracing, from beyond the discipline, the network that nourishes it. A discipline is never simply the site it claims. Calling into question this practice of siting shifts the map. An autistic child's wander line, Deligny reminds us, should never be reduced to the interpersonality of simple location, to the inter of child and site. It is emboldened and embedded by the relations that activate and orient it.

2. An immense field of knowledge of the real is activated through the drawing, and the drawing on, of the wander lines. 'Adopt a humble attitude in the face of the immense field of knowledge of the real' speaks directly to what the wander line carries, reveals and conceals in both its movement and the attunement to what moves in excess of it. The concealment of what exceeds the line is not about obfuscation. It is about an incapacity for the moving to catch and contain all that matters, all that makes a difference.

When Deleuze speaks of the need to foreground the indefinite article when it comes to the child, 'a child', when he speaks of the 'any child whatsoever' (enfant quelconque), he is speaking of the quality of moving that troubles inscription. He is speaking of what escapes with the line, of what escapes the line. Becoming-child, the indefinite child quality that moves across all lifeliving but is in a particular approximation of proximity to the child, is antidote to method, to site, to simple location. A becoming-child is a childing-worlding, to 'reach a childhood of the world, restore a childhood of the world' (Abécédaire, 'Enfance').

The real is always both actual and abstract, pragmatic, and speculative. The becomingchild of the indefiniteness of a childing-worlding is never conceived as a generality. All acts are lived abstractions. Children teach this not by being closer to nature, but by being more attentive to the angular interstices through which the relational folds of experience make themselves felt.

Child in the indefinite is not a negation of a singular lived experience. It is an addendum to it, an excess over it. Child in the indefinite is an expression of a minor sociality that moves across a field of relation, a sociality attuned to what weaves experience in the making. Consider the account below of a conversation between a young child and a teacher on the making of a book: 
Eva: We have made a book.

Teacher: Oh really, what is the book about?

Eva: Oh, it isn't about anything, we didn't write anything in it.

Teacher: But surely, you did something with it?

Eva: Yeah, I started to draw a palm tree and a beach and then Agnes saw that and

wanted to do the same thing, and then Ella followed and so on and so on

(smiles and makes signs with her arms showing how everything just rolled on)

[Pause]

Eva: (looks at the teacher) That's what the book is about.

(Olsson, 2013: 730).

The child is not an empty vessel hoping to be filled by content devised by adults. Nor is the child a neutral entity moving along a pre-constituted developmental path. A child is a researcher of life, and a maker of worlds. The indefinite runs through the child, protecting it from the frames we so eagerly wish to impose on it. The becoming-child promises no return to an innocent beginning. There is no inner child. What there is, in every line, is an indeterminate tendency for resonating with what else moves across it. This is the becoming-child of the line.

The real moves here, at the cusp where the line and the network co-compose, in the field of relation their co-composition sparks.

What is the book? In the humble attitude toward childing-worlding, this is always a new question. Certainly, the book must not be reduced to its content as though it already knew what it could do. Adopting a humble attitude in the face of the immense field of the real involves listening to what else the book activates in the child's account of bookness.

Liselott Olsson writes of a project concerned with the alchemy of language. This project The Magic of Language - led by Olsson, Ebba Theorell, and Gunilla Dahlberg, takes the question of what else bookness might be as the problem of language. What else is at stake in the languaging, they ask? Certainly not content, simply understood: 'Oh it isn't about anything, we didn't write anything in it'. The book is about all it brings into relation. The book is the condition for an emergent account of a language in the making. 'Yeah, I started to draw a palm tree and a beach and then Agnes saw that and wanted to do the same thing, and then Ella followed and so on and so on ... That's what the book is about.'

The humble attitude is not toward the child. It is toward the activity of worlding. What else is the book capable of doing? What can it teach us? Here, the child knows something the adult has not yet attuned to, too concerned, as is often the case, with the presumed overlay of content and form. For the child, the book is much more complex. It is the vector-quality of a set of relations, a force-field that orients conditions that might otherwise go unregistered. Is content is its excess-over-form. 
3. The heterogeneous dialogue that allows the agencement of expression to be felt must not be reduced simply to humans, must not ignore all else it brings into resonance. ${ }^{3}$ An agencement has the capacity of unravelling an existing formation. 'Open one's own assemblages towards heterogeneous fields of dialogue and other forms of mutual exchange', write Guattari and Vilnar. A discipline is always fragile at the edges. It is a question of exploring the ecologies it depends on, drawing new diagrams.

Frequent assumptions are made about what counts as knowledge. Hierarchies of value are rarely addressed. In the field of early childhood education, it is not uncommon to hear that children's education is an investment in their future. 'Early childhood is seen as the first stage in the process of producing a "stable, well prepared" workforce for the future, and thus a foundation for long-term success in an increasingly competitive global market' (Dahlberg, et al., 2013: 48). It is assumed that children come to learning to increase a bank of knowledge that will be invested in their future endeavours. The logic of the vessel doesn't end there: the adults of our universities are still waiting to be filled, our classes too often planned according to linear accounts of what kind of information should come first and what methods should frame it. The emptiness of the reservoir persists because it allows power to operate by placing knowledge in the hands of the few, aided, more and more, by accounts of neoliberal education that weaponize productivity over process.

But like the child who is not an empty vessel, knowledge is not a form. The child in the indefinite reminds us that knowing is a verb that worlds, and as such must never be reduced to a set of retrievable operations. Knowing is not about filling a person up. Knowing is about finding a way, fielding a map.

The becoming-child is often read as a kind of time-travel as though the force of becoming were about returning to an earlier time. This is to misunderstand the temporality of becoming. Becomings are transversal. They are atemporal (dis)orientations that amplify minor tendencies at work.

Becoming is an approximation of proximity, not an analogy. To become is to be reoriented by the germs of existence in formation. 'Becoming is to emit particles that take on certain relations of movement and rest because they enter a particular zone of proximity' (Deleuze and Guattari, 1989: 273).

The zone of proximity becomings foster is not fail-safe. The major captures the minor at every turn. All becomings are vulnerable to the templates of existence.

This is the power of the indefinite - that it is not a form to be sustained, but a tendency to be practiced.

\footnotetext{
${ }^{3}$ In the English, agencement is translated as 'assemblage'. Assemblage loses some of the movement of agencement which foregrounds the activity of catching a process underway. I therefore tend to use agencement where possible, thereby foregrounding not the 'agency' of a process but its activation of an ecology. For a more detailed engagement with agencement as a concept that challenges what I call the volition-agency-intentionality triad, see 'Carrying the Feeling' in The Minor Gesture (Durham: Duke UP, 2016).
} 
When we encounter the vector-quality of the becoming-child it is not the line from here to there that stands out, but the force of the indefinite that tranversalizes it. It is not less-than, not smaller-than. The difference between the major and the minor is not one of scale: its minority is heard in the angularity of its attunement. The minor moves across, diagonalizing the line while following it. This double-gesture of following and remaking is the force of all speculative pragmatism, and no one knows this better than the child-researcher. The child's 'why' question is never, after all, a question that could properly be answered. It is a question that begs a worlding.

Deleuze and Guattari speak of children's questions as 'question-machines', operations for clearing paths toward more complex qualities of relation. What a child asks is not that we define experience in advance, but that we make it. 'That's what the book is about'.

4. The problem is not with specialization per se. I wouldn't want to suggest that the child's question is not precise. When a child asks about the planets in the solar system, she doesn't want to hear about tulips or deer. The question of the planet has a texture of experience that is all its own, and this specialization has to be taken at its word. This is what Guattari and Vilar mean, I think, when they say that we should 'not abandon specialization as an ideological principle but, rather, proceed irreversibly by fluctuation and bifurcation towards transdisciplinarity, each discipline according to its own speed and willingness to make sacrifices or suffer amputations'.

What is a planet? Is it limited to a system defined as solar? Is the shape of it what draws a child in? Or its distance? Its unknowability? Or is it the quality of awe that is experienced in a drawing of it that can't quite grasp its strange luminosity?

In the The Magic of Language, the texture of thought and action is always at the forefront in the work with children. The aim here is not to refute specialisation, and never to discount precision, but to recognize that all knowledge is built in a field of relation. Specialisation is at its most potent when in contact with the worldings it calls forth. Olsson writes: 'Just as young children seem to prefer to stay in the spheres of invention, formulation and construction of questions and problems, they likewise seem to prefer working with the production, rather than the acquisition, of linguistic representations' (2013: 234). In the making, in the learning, the becoming-child opts not for knowledge wrapped by others. The becoming-child leans into the problem, a researcher already deeply aware that the conceptual force of thought emerges through the crafting of a problem. 'The children's questions are all extremely precise and pointed questions: all of a sudden there's a hole in the ground; now, how to move?' (Olsson, 2013: 241). A gnawing focus, a compulsive return on an idea - a specialization - is always worthy of celebration. The aim is not to generalize. The work is to demonstrate, in the act, how that obsession produces a bifurcation, a transduction.

When we move at the speed of a problem the question is not one of percentages - how much disciplinarity, how much interdisciplinarity? The transversality of the problem leads the inquiry. Amputations are at the ready. All that is not necessary for the problem at hand will fall to the wayside. The shape of thinking emerges in the movement of thought, leaving all it doesn't need behind. To study is to learn to respond to what moves the thinking that makes us. 
5. There are always risks involved. Amputations may come back to haunt us. We may have lost our way, following a line of inquiry that in the end couldn't coagulate into a problem. False problems abound.

The fifth proposition: 'Certain theoretical approaches will need to be deconstructed, but hopefully not in an anarchic way so that existing disciplines may see the confluence of concepts and problems from a new theoretico-pragmatic and virtual perspective'. The proposal is complex: work with what is there, listen to what is already moving. Don't cut too quickly what might otherwise feed the process. Be sensitive to what else is moving through it.

And yet, sometimes an anarchic break with all that has been colonially held onto is absolutely necessary. How to stage the balancing act between these two tendencies?

bell hooks speaks of engaged pedagogy in the context of what she calls the 'banking system' of the university (2015). Too often education is an endgame set up to guarantee the power structures already in operation. Neurotypicality is its frame, which is to say, whiteness, a baseline exclusive to its core.

And so, anarchy may indeed be called for in dismantling the regimes that keep the structure in place. Engaged pedagogy depends on it.

The choice to work against the grain, to challenge the status quo, often has negative consequences. And that is part of what makes that choice one that is not politically neutral.

Ideally, education should be a place where the need for diverse teaching methods and styles would be valued, encouraged, seen as essential to learning. Occasionally students feel concerned when a class departs from the banking system. I remind them that they can have a lifetime of classes that reflect conventional norms. (hooks, 2015: 206)

Practice must accompany the anarchic gesture: dismantle by making a way, by orienting toward the folds of speculative thought otherwise unheard. Study, don't just sprinkle the experience with diversity. It is not about adding a few texts. It's about corrupting the banking system, about turning it upside down, about shifting the conditions that created it. In Moten and Harney's words, engaged pedagogy demands that we 'tear this shit down completely and build something new' (2013: 152).

6. There is an exercise in Aikido that has you hold an opponent's wrist tightly in a gesture of combat. The aim of the exercise is to demonstrate how quickly, in the holding of the opponent's wrist, their attention is drawn to the site of coercion, how quickly they forget how much more movement-affordances their bodies possess. When Guattari and Vilnar remind us that 'the creation of numerous cross-references is not heresy but has always existed to some extent' we also hear in their words all that has been staged to keep us from that complexity. Every attempt to remind us that excessive curiosity distracts us from proper knowledge acquisition, that transdisciplinarity impoverishes knowledge by emphasizing lateral thinking, that knowledge is at 
its most powerful when it is contained, owned, leads us back to the heretic nature of transversality. To know is to hold knowledge, not to move with it. Disciplines must be disciplined.

Marie Battiste recognizes the violence of this disciplining gesture in the ways Indigenous knowledge is moved through education in Canada. When Indigenous thought is presented as a side-dish in the neurotypical context of the university as banking system, what occurs is a fetishization of a generalized figure of Indigeneity. This occurs not only through the teachings of Indigeneity that too often presume it is a single culture in a single place, but also through the pedagogical presuppositions themselves. As Battiste emphasizes: 'Aboriginal students do not have a single, homogenous learning style' (2013: 176). Decolonizing education, Battiste suggests, should always involve 'legitimiz[ing] the voice of all Aboriginal people through place and culture' (2013: 176).

Leanne Betasamoke Simpson is fiercer in her dismissal of colonial structures, refusing to accept that decolonization can happen in those very systems that produced it. 'If we accept colonial permanence, then our rebellion can only take place within settler colonial thought and reality' (2014: 8). In 'Land as Pedagogy', she questions the very possibility of the university as site for Indigenous ways of knowing. The land is the site of knowledge, she writes, its rich stories a code of ethics. The university, on the other hand, is the ongoing site of colonial domination.

The sparking of a transversal quality of knowing requires a commitment to the singular forces of expressibility where they take hold and make a difference. In the context of what Sandy Grande (2014) calls 'red pedagogy', the ethos of the land is the living matrix that calls forth a complex rethinking of how knowledge expresses itself. The power of the more-than human here takes us back to the agencements of the third proposition, the reminder that other forms of mutual exchange are always at work in the transversality of thought in the moving.

7. Lakota Pochedly writes that '[u]ltimately, I believe decolonization is not about describing or defining, it is about doing' (2004: 289). The seventh proposition catches up with the fifth, returning to the anarchic. 'From a critical interdisciplinary perspective, certain scientific positions of alleged self-sufficiency and omnipotence will be subject to definitive critique'. Some things just can't continue as they are. Tearing the shit down and building it anew is not a reprisal of academic critique, that gesture of cutting down from a distance. To tear the shit down and build it anew is to engage in the politics of pedagogy, to push pedagogy to the limits of practice and ask whether shoring up the same system over and over again with a slightly different set of tools has anything at all to do with learning.

To decolonize is to practice otherwise. For those who are Indigenous, it is to return to the land and to learn from what is has to teach, exploring the transversal potential of worldings philosophical, agricultural, aesthetic. '[D]ecolonization is not a project for justice, it a project of Indigenous liberation of governance, education, land, traditions, and jage nagonan (all our relations)' (Grande, 2004; Tuck and Yang, 2009). For those not Indigenous, it must also be a practice: decolonization is more than a shift in the syllabus, more than a turn of the canon. Decolonization is a way of living. Of childing-worlding. 
When Loris Malaguzzi speaks of children losing ninety-nine of their hundred languages, he is warning us of the danger of education to steal from children the power of knowing. To steal from children, from the becoming-child, is to unworld. Settler-colonialism has been a dedicated practice of unworlding. Alongside and through neoliberal capitalism the unworlding continues. Colonialism is what we depend on to understand the discipline, the territory. Much less has changed than we would like to admit.

Reggio Emilia is the site where Malaguzzi explored the hundred languages of children over many decades, and remains a site where education continues to be challenged. The story of Reggio Emilia is humble: a small town destroyed by WWII in need of schools found itself committed to building them, one brick at a time by farmers on a piece of farmland. 'There were piles of sand and bricks, a wheelbarrow full of hammers, shovels and hoes. Behind a curtain made of rugs to shield them from the sun, two women were hammering the old mortar off the bricks' (Malaguzzi, 2011: 28). Shortly after liberation, the People's Nursery School of Villa Cella was born. Others followed: 'What happened at Villa Cella was but the first spark. Other shcools were opened on the outskirts and in the poorest sections of town, all created and run by parents' (Malaguzzi, 2011: 29). Resources were scarce, and yet more schools emerged, and with them the first cityrun school in 1963. Although pressured by the Church to keep education under its mantle, Reggio Emilia fought back, one school at a time, until, in the mid-1970s, the success of these emergent operations spoke for itself. Built on relation, the aim throughout the network of schools, many of them dedicated to the youngest children, is to situate the child in an ecology that includes the environment, the family, the institution. Children are not empty vessels, but nor is the education 'child-centered'. Education is embedded, the curriculum invented in the making, the child a vector in the field of relation facilitated by the learning itself.

What makes Reggio Emilia stand out amongst educational initiatives is its refusal to segregate: students with disabilities receive priority and mainstreaming is the norm. This is not about inclusion in the simplistic sense. It is about inventing a way, about working with the collectivity emboldened by an education relational to its core. In Malaguzzi's words, 'Children "write" in many ways, including movement, painting, sculpture, and computer animations. Give the children a number of ways to make their thinking visible' (2011: 7). Inclusion is an experiment in attending to the quality of difference that resonates across a learning that moves through the teacher-parent-child assemblage but is not reduced to it. To make thinking visible is to move with careful attention to the worldings it activates.

The Reggio Emilia school system believes that 'things about children and for children are only learned from children' (Malaguzzi, 2011: 30). The emphasis on 'the children's approach to life [as] a kind of research' is not a return to an individualist, child-centric approach. Quite the opposite: the orientation is always transversal. The aim is not to site the child but to learn with the child how the world comes to expression. This approach relies on vectorizing the becomingchild of the adults who collaborate with them, exciting their sense of how else learning can happen. 'It is important for pedagogy not to be the prisoner of too much certainty but instead 
to be aware of both the relativity of its powers and the difficulties of translating its ideals into practice' (Malaguzzi, 2011: 37).

Simpson writes:

For countless generations, Nishnaabeg children grew up within the milieu of Nishnaabewin, not within the institutionalized schooling system. Many of our children still do, thanks to parents, grandparents and communities. Like governance, leadership and every other aspect of reciprocated life, education comes from the roots up. It comes from being enveloped by land. An individual's intimate relationship with the spiritual and physical elements of creation is at the centre of a learning journey that is life-long (Deloria, 2001: $60)$. You can't graduate from Nishnaabewin; it is a gift to be practiced and reproduced. (2014: 9)

To allow the learning to lead the relation is to expose the weakest link in most educational practices: the belief that we can graduate to become holders of knowledge. In 1916, Dewey wrote with disdain that '[h]ow one person's abilities compare in quantity with those of another is none of the teacher's business' (1916). To be in the role of teacher has come to mean to be in the role of evaluator. In Reggio Emilia's system, there is no evaluation. Speaking of the lack of failure in their system, Gambetti emphasises that'there is absolutely no need [to fail students] because we don't teach to children's weaknesses, we teach to children's strengths' (cited in Dodd-Nufrio, 2016). What Grande calls 'red pedagogy' is not an analogue to Reggio Emilia. But in many ways, their orientations are compatible. The difference, of course, is the context, the ongoing and unspeakable violence toward First Nations children and the renewed potential of becoming-child of all that is expressive in the aftermath of a colonialism that never ends. It is in this context that Simpson writes of a necessity to turn away from any state-centred system back to the land which has always known how to give, and how to listen. In her manifesto for the Assembly of First Nation's conference on education, she calls for 'turning inward' (n.d.). Despite hard work on the part of educators, 'the system," she writes, 'is doing exactly what it was designed to do'. It is 'train[ing] people to uphold colonialism by silencing Indigenous languages, by erasing the history and contemporary reality of Indigenous-state relations and by ignoring Indigeous intellectual traditions'. 'What if we stopped looking for colonial accreditation and recognition in education', she continues. 'What if we purposefully educated our own?' Purposeful education has nothing to do with accreditation. Accreditation is nothing more than a business, a banking system (Simpson, n.d.).

Transversal operations for the creation of ways of knowing emerge from the ground up. They are singular and speculative at once, emboldened by the creativity of the everyday. The mistake is to assume that what education needs is a model. What education needs is an opening for learning, an operative interstice for seeing beyond the map. 
8. Seeing beyond the map involves the crafting of enabling constraints at each step of the way. The risk of child-centered approaches to education is the reification of the child as entity, as the burgeoning capitalist figure of the self-enclosed individual. The becoming-child is its counter, a vector quality for the multiplication of childness, an operative indeterminacy in a field of relation that connects and composes. We are those children, always in excess of our-selves. Accreditation shuts that down, reducing us to the value we have on the transactional marketplace.

The final proposition - 'intradisciplinary graspings of the virtualities of heterogeneous, evolving fields will have repercussions for the movement towards transdisciplinarity' - is a reminder that transaction is never transversal. Enabling constraints are not maps-becomediagrams. Metamodeling is not a system; it is a transversality. To see the interstices requires a map that transversalizes expectations.

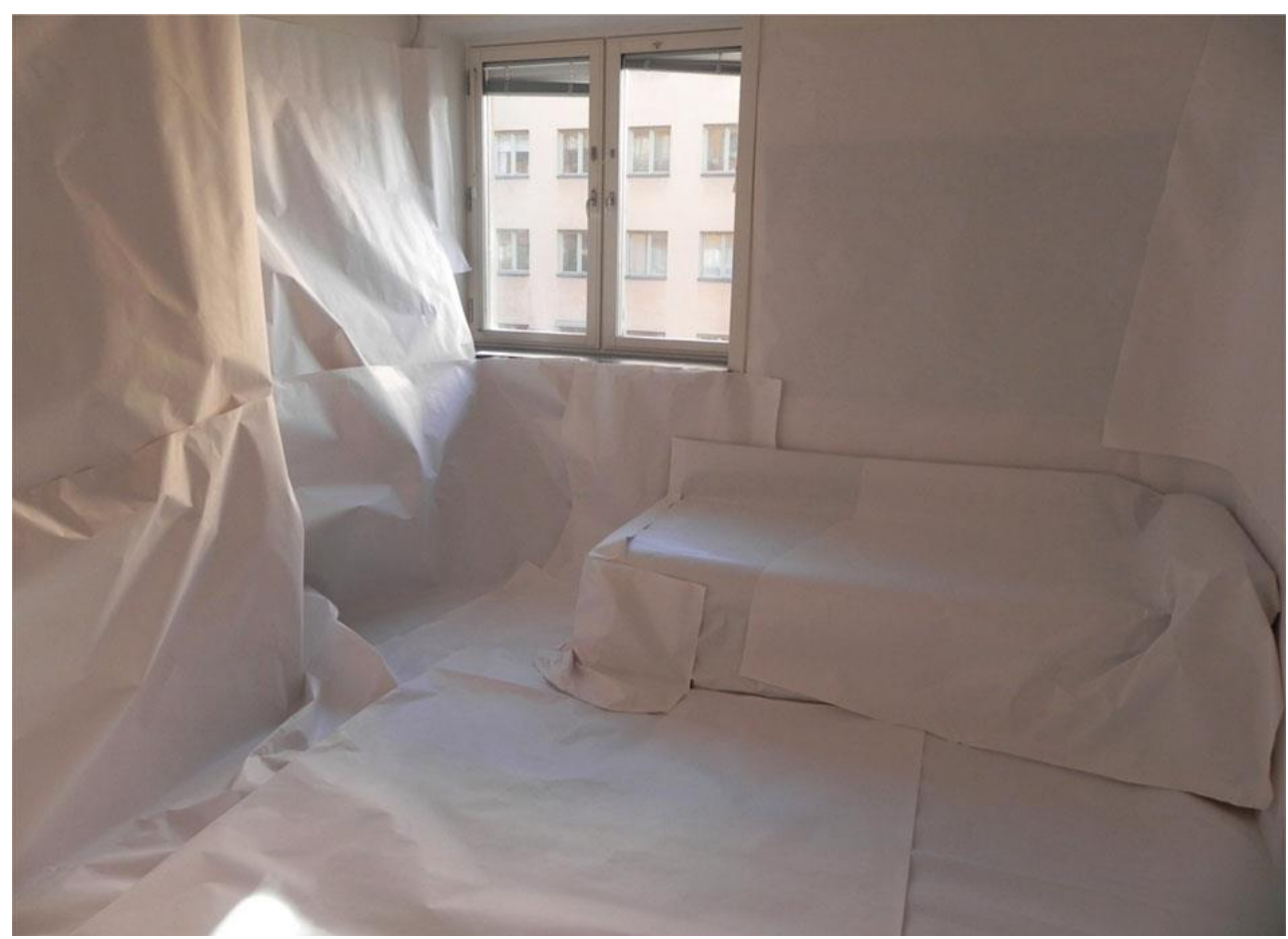

Figure 2: A final image. A paper room. A papering over of expectations. An anarchitecting.

This proposition, part of The Magic of Language project, is an invitation to compose. The question: how do we trace those movements which move us? And, what else can a book become?

We needed to find a way to latch on to children's apparent desire to [let] the Book encounter the world. Taking this use of the book as a 'connector' to the world into account, gave us the idea to displace the reading and writing - from the individual child and from the book as a product - out to the entire room. This is how the choice to offer a Paper Room to the children came about. (Dahlberg, et al., 2015: 730-731)

The paper room calls forth a desire to mark and be marked, but this marking cannot be reduced to the purely linguistic for the room creaks and cracks with each step, its rustling a 
choreographic proposition to move otherwise, to listen otherwise. No surprise, then, that the children's response upon entering was one of 'care and caress' and that they were drawn in, compelled to explore with intensity what the room could do (Dahlberg and Olssen, 2016: 731).

How to register the effects of a book-room that papers over our expectations of where language is situated in the worlding? 'What new existential universes are offered?', ask Dahlberg and Olssen? (2016: 733). What modes of existence are catalysed? Their answer is not unexpected: schizoanalytic tendencies are expressed in this proposition to make felt how else language resonates. 'This collective experimental and analytical work can be seen as a form of clinical practice, a form of diagnostic competence that serves prospectively and as a catalyst for events to come' (2016: 733).

Book-rooms are worlds in the making. What is revealed by them is how the transversal operation of metamodelings always exceeds the frame. What matters is not what drawings the children made but how the drawings revealed potential worlds. How the drawings diagrammed wander lines that are magnetized by the excess over itself of experience.

This anarchic share of experience in the making is what Dahlberg and Olssen gesture toward in their account of the clinical aspect of the work. The force of the proposition is that it reveals the shape of an anarchiving. This is radical pedagogy - an attunement to what seeds a thinking in the act.

To catch resonances of a work's work is to amplify the share of the speculative that runs through its pragmatic operations. What the anarchiving can do, by prolonging the anarchic share that courses through the event, is make felt what resisted registering, and value it. To build it anew is the mantra, recognizing that to build can be a minor gesture, a diagonal operation, an oblique expression of what else runs through the magnetized worldings the wander lines call forth. Tito Mukhopadhyay may not have spoken-language but he certainly has the other 99 . We have no idea what we know. Value must never be reduced to an external evaluation. In Deleuze's words, 'If little children managed to make their protest heard in nursery school, or even simply their questions, it would be enough to derail the whole educational system' (2004b: 208).

Metamodelings of knowledge in the making are never generalizable across contexts. Each worlding creates its own wander lines. The work is to become sensitive to what their overlay makes visible. The university, the preschool, the land, three images of thought, the becomingchild cutting across them, in indeterminate angularity. What connects them? The shape of a problem: how to amplify the fierceness of knowing against constituencies committed to the muting of its force?

\section{Author Biography}

Erin Manning is a research chair in Speculative Pragmatism, Art and Pedagogy in the Faculty of Fine Arts at Concordia University (Montreal, Canada). She is also the founder of SenseLab (www.senselab.ca), a laboratory that explores the intersections between art practice and philosophy through the matrix of the sensing body in movement and 3Ecologies Institute collaborator. Artworks tend to explore more-than human participatory ecologies. Exhibitions 
include the Sydney and Moscow Biennales, Glasshouse (New York), Vancouver Art Museum, McCord Museum (Montreal) and House of World Cultures (Berlin) and Galateca Gallery (Bucarest). Publications include For a Pragmatics of the Useless (Duke UP, 2020), The Minor Gesture (Duke UP, 2016), Always More Than One: Individuation's Dance (Duke UP, 2013), Relationscapes: Movement, Art, Philosophy (Cambridge, Mass.: MIT Press, 2009) and, with Brian Massumi, Thought in the Act: Passages in the Ecology of Experience (Minnesota UP, 2014).

\section{References}

Battiste, M. 2013. Decolonizing Education: Nourishing the Learning Spirit. Saskatoon: Purich Publishing.

Dahlberg, G., Moss, P. \& Pence, A. 2007. Beyond Quality in Early Childhood Education and Care. Languages of Evaluation. 2nd Edition. London: Falmer Press.

Deleuze, G. 2004a. E comme Enfance, in Boutang, P.A. \& Parnet, C. L'abécédaire de Gilles Deleuze. DVD. Paris: Editions Montparnasse

Deleuze, G. 2004b. The Logic of Sense. London: Continuum.

Deleuze, G. \& Guattari, F. 1989. A Thousand Plateaus, trans. B. Massumi. Minneapolis: Minnesota University Press.

Deligny, F. 2018. Oeuvres. Paris: Arachnéen .

Deligny, F. 2015. Arachnean and Other Texts, Trans. D. Burk \& C. Porter. Univocal, University of Minnesota Press.

Dewey, J. 1916. Democracy and Education. New York: Dover. Available at: https://www.gutenberg.org/files/852/852-h/852-h.htm (accessed 23 September 2020).

Dodd-Nufrio, A.T. 2011. Reggio Emilia, Maria Montessori, and John Dewy: Dispelling teachers' misconceptions and understandings theoretical foundations. Early Childhood Education Journal, 39: 235-237.

Edwards, C., Gandini, L, \& Forman, G. 2011. The Hundred Languages of Children: The Reggio Emilia Experience in Transformation. Westport: Praeger.

Genosko, G. 2003. Félix Guattari - Towards a transdisciplinary methodology. Angelaki, 8(1): 129140.

Grande, S. 2004. Red Pegagogy: Native American Social and Political Thought. London: Rowman and Little Publishers.

Harney, S. \& Moten, F. 2013. The Undercommons: Fugitive Planning and Black Study. Wivenhoe: Minor Compositions.

hooks, b. 2015. Teaching to Transgress: Education as Practice of Freedom. London: Routledge.

Malaguzzi, L. 2011. Loris Malaguzzi and the Schools of Reggio Emilia: A Selection of his Writings and Speeches 1945-1993. London: Routledge.

Manning, E. 2016. The Minor Gesture. Durham: Duke UP.

Manning, E. 2013. Always More Than One - Individuation's Dance. Durham: Duke UP.

Mukhopadhyay, T. 2011. The Mind Tree. New York: Arcade Press. 
Olsson, L. M. 2013. Taking children's questions seriously: The need for creative thought. Global Studies of Childhood, 3(3): 230-253.

Olsson, L. M., Dahlberg, G. \& Theorell, E. 2015. Displacing identity - placing aesthetics: early childhood literacy in a globalized world. Discourse: Studies in the Cultural Politics of Education, 37(5): 717-738.

Pochedly, L. 2015. Keep calm and decolonize - Response 5. In Grande, S. Red Pedagogy: Native American Social and Political Thought. $10^{\text {th }}$ Anniversary Edition. London: Rowman and Little Publishers, 289-294.

Simpson, L. B. 2014, Land as pedagogy: Nishnaabeg intelligence and rebellious transformation. Decolonization: Indigeneity, Education \& Society, 3(3).

Simpson, L. B. n.d. Turning Inward and Purposely Educating Ourselves. Available at https://www.leannesimpson.ca/writings/turning-inward-purposefully-educating-ourown (accessed 23 September 2020).

Whitehead, A. 1938. Modes of Thought. New York: The Free Press. 